\title{
MORPHO-PHYSIOLOGICAL RESPONSE OF HYBRID MAIZE (Zea mays L.) TO SALT STRESS IN COMBINATION WITH EXOGENOUS CALCIUM APPLICATIONS
}

\author{
KHAN, A. $.^{*}-$ AHMAD, R. ${ }^{1}-$ AfSAR, S. ${ }^{1}-$ ZAFFAR, H. ${ }^{2}-$ BAIG, A. $^{1}-$ MUgheES, M. ${ }^{1}-$ \\ SHAH, M. M. ${ }^{1}$ \\ ${ }^{1}$ Department of Biotechnology, COMSATS University Islamabad, Abbottabad Campus, 22010 \\ Abbottabad, Pakistan \\ ${ }^{2}$ Department of Environmental Sciences, COMSATS University Islamabad, Abbottabad \\ Campus, 22010 Abbottabad, Pakistan \\ Corresponding author \\ e-mail:asma_quaidian@yahoo.com
}

(Received $7^{\text {th }}$ Jan 2020; accepted $6^{\text {th }}$ May 2020)

\begin{abstract}
Maize, the third most important cereal crop around the globe, is hampered by devastating abiotic factors including salt stress. Calcium is known to increase plant tolerance to biotic and abiotic stresses by influencing physiological processes. The current study was carried out to investigate the genetic variation of maize hybrids against salt stress in combination with exogenous application of calcium $\left(\mathrm{Ca}^{2+}\right)$ in a hydroponic culture. Three levels of salinity, each with $\mathrm{NaCl}(0 \mathrm{mM}, 75 \mathrm{mM}$, and $150 \mathrm{mM})$ and $\mathrm{Ca}^{2+}(0 \mathrm{mM}$, $2.5 \mathrm{mM}, 5 \mathrm{mM}$ ) were applied to maize hybrids in three replications and data were recorded for key morpho-physiological traits. The results showed that all concentrations of $\mathrm{NaCl}$ significantly affect the maize hybrids with Sarhad White Azad Jammu Kashmir (SWAJ 6,7) and Syngenta 8441 being the least affected by both $75 \mathrm{mM}$ and $150 \mathrm{mM} \mathrm{NaCl}$ concentrations. The exogenous application of $2.5 \mathrm{mM} \mathrm{Ca}^{2+}$ with $75 \mathrm{mM}$ salt concentration showed significant effects on all morpho-physiological traits of maize hybrids. Better growth performance, maintenance of nutrient contents, lower accumulation of toxic sodium ions and lower $\mathrm{Na}^{+} / \mathrm{K}^{+}$in SWAJ6,7 and Syngenta 8441 indicate that these maize hybrids are more tolerant to salinity stress than the others under study.
\end{abstract}

Keywords: hydroponic, ion contents, Zea mays L.), $\mathrm{NaCl}$, proline

\section{Introduction}

Soil salinity is one of the key environmental constraints that limit the production of crop throughout the world (Jiang et al., 2018). In arid and semiarid regions, the soil salinity more severely affects crop production due to global climate changes and as consequences of irrigation practices (Farooq et al., 2015). In Pakistan around 6.8 million hectares of land is affected by salinity. Therefore, major agricultural area remains uncultivated (Chaudhary et al., 2017). Saline soils have high $\mathrm{pH}$ and electrical conductivity (EC $>4.0 \mathrm{dS} / \mathrm{m}$ ) and are usually rich in sodium, chloride and sulfate ions, with high absorption rate of sodium (Flowers and Flowers, 2005). In the rhizosphere, osmotic pressure due to high saline condition reduces mineral and water uptake by the plant, which ultimately affect primary and secondary metabolism of the plant (Hendawy and Khalid, 2005). The cumulative response of meristematic and expanding cells to salt stress is the inhibition of shoot growth which is observed primarily under salinity stress (Shoresh et al., 2011). Salt stress causes various morphological and metabolic modifications in plants by creating osmotic stress and ionic imbalance thus disrupts the vital cellular functions (Taylor et al., 2004; Yildirim et al., 2006). Osmotic stress leads to the reduced water absorption by roots and increase water loss from leaves. This 
mechanism is called hyperosmotic stress and it leads to various physiological modifications in plants such as nutrient imbalance, decreased photosynthetic activity, decreased stomatal apertures, membranes interruptions, modifications in antioxidant enzymes and failure to detoxify reactive oxygen species (ROS) (Soliman and El-Shaieny, 2014). The formation of ROS due to salt stress interrupts vital cellular functions by causing damage to various cell components such as DNA, protein and lipids (Gupta and Huang, 2014). Plant tissues exposed to saline soil accumulate more $\mathrm{Na}^{+}$and $\mathrm{Cl}^{-}$which is one of the most detrimental effect as it causes severe ionic imbalance in plants by decreasing uptake of important mineral ions which are essential for the growth and development of plant (James et al., 2011). Reduced water permeability and aquaporin abundance of membrane under salinity stress is restored by calcium treatment (Martínez-Ballesta et al., 2008).

Calcium, an essential plant nutrient is responsible for the maintenance of structure and functions of plant membranes. It also increases the stability of cell wall structures, selectivity and transport of ions and improves the metabolic activities in plants. Calcium as second messenger plays a crucial role in signal transduction in response to developmental and environmental signals (Guo et al., 2019). Almost half of the cellular $\mathrm{Ca}^{2+}$ is bound mainly to carboxyl groups of pectins in the cell wall (Cramer, 2002). Previous studies indicated that salt induced inhibition of growth is improved by high content of $\mathrm{Ca}^{2+}$ bound to pectin on cell wall (Madea et al., 2005). Increased $\mathrm{Na}^{+}$ions due salinity stress reduces calcium availability and its transport to growing regions of the plant (Shoresh et al., 2011). The reduction of $\mathrm{Ca}^{2+}$ concentration in salinized plants severely effects the physiological function. The addition of supplemental $\mathrm{Ca}^{2+}$ provide protection by stabilizing on the cell-wall components (Tuna et al., 2007).

Maize (Zea mays L.), an important cereal crop is grown under wide range of soil and climatic conditions. It is an important $\mathrm{C} 4$ plant belongs to the grass family Poaceae (Farooq et al., 2015). About 21\% of the total maize grain produced is consumed as food throughout the world (Chaudhary et al., 2017). The larger producer of maize is the United States with annual yield of about 4096190 thousand million tons. In Pakistan average yield of maize is $4268 \mathrm{~kg} / \mathrm{ha}$ (Economic Survey of Pakistan, 2012-13). Various biotic and abiotic stresses extremely affect the yield potential of maize crop. Among abiotic stresses, salinity reduces the maize yields by causing numerous biochemical and physiological changes in plants (Zafar-ul-Hye et al., 2014). Maize is found to be moderately sensitive to salt stress. However, extensive genetic variation exists intra-specifically in maize for salt resistance (Mansour et al., 2005). The current study was aimed to explore the genetic variation of five different maize hybrids against salt stress in combination with exogenous application of $\mathrm{Ca}^{2+}$.

\section{Materials and Methods}

In order to investigate the influence of exogenously applied $\mathrm{CaSO}_{4}$ as calcium source on five maize hybrids under salt stress, an experiment was conducted in 2018 under hydroponic conditions in the greenhouse of COMSATS University Islamabad, Abbottabad Campus, Pakistan. Maize hybrids used in current study were:

COMSATS Random Mating 8 (CTRM 8), Pirsabak Experimental Variety 2 (PSEV 2), Sarhad White Azad Jammu Kashmir 6, 7 (SWAJ 6, 7) and Syngenta 8441. 


\section{Plant growth and experimental treatments}

The seeds of five maize hybrids (CTRM 8, PSEV 2, SWAJ 6-7, Syngenta 8441 and XPW3) were sterilized with $1 \% \mathrm{HOCl}$ for 10 minutes and rinsed with distilled water, the process being repeated 3 times. The seeds were germinated on moist thin sheets of foam at $25^{\circ} \mathrm{C}$ in an incubator. After germination, uniform sized seedlings were transferred in constantly aerated pots containing $1 / 3^{\text {rd }}$ strength Hoagland's solution. Plants were adapted to full strength nutrient solution in $25 \%$ increments every second day in similar way as described by Richter et al. (2015). The experiment was carried out in a completely randomized design (CRD). Plants were subjected to different concentrations of $\mathrm{NaCl}$ along with application of $\mathrm{Ca}^{2+}$ as foliar at four leaf stage. Seven different treatment combinations with three replicates per treatment were used. Treatment combinations were as follow:

T1: Control (Hoagland solution alone); T2: Salt Stress ( $75 \mathrm{mM} \mathrm{NaCl}$ ); T3: Salt stress and foliar $\left(75 \mathrm{mM} \mathrm{NaCl}+2.5 \mathrm{mM} \mathrm{Ca}^{2+}\right)$; 4 : Salt stress and foliar $(75 \mathrm{mM} \mathrm{NaCl}+5 \mathrm{mM}$ $\mathrm{Ca}^{2+)}$; T5: Salt Stress (150 mM NaCl); T6: Salt stress and foliar $(150 \mathrm{mM} \mathrm{NaCl}+2.5 \mathrm{mM}$ $\left.\mathrm{Ca}^{2+}\right)$; T7: Salt stress and foliar $\left(150 \mathrm{mM} \mathrm{NaCl}+5 \mathrm{mM} \mathrm{Ca}^{2+}\right)$.

\section{Growth parameters}

Growth parameters were scored at seventh day of treatments application by measuring leaf number, leaf area, shoot length and maximum root length. Fresh weights of plants were taken immediately after harvesting. For dry weight, plant organs were placed in an incubator at $75^{\circ} \mathrm{C}$ for $72 \mathrm{hrs}$ (Sun et al., 2018). Leaf area was calculated according to Equation 1:

$$
A=L L * W * K
$$

where,

LL represents leaf length,

$\mathrm{W}$ is the maximum width and

$\mathrm{K}$ is a shape factor with value 0.75 .

\section{Chlorophyll content}

Chlorophyll extraction was done by grinding $0.1 \mathrm{~g}$ of fresh leaves in $15 \mathrm{ml}$ of acetone $(80 \%)$. This mixture was then subjected to centrifugation at $5000 \mathrm{rpm}$ for 10 minutes at $4^{\circ} \mathrm{C}$. Supernatant from each sample was collected until the residue was turned into colorless mixture. The chlorophyll content was measured using spectrophotometer at wavelength of $645 \mathrm{~nm}$ and $663 \mathrm{~nm}$ (Nayyar et al., 2005).

\section{Relative water content}

Relative Water content (RWC) was determined according to Equation 2 as described by Loutfy et al. (2012).

$$
R W C(\%)=[(F W-D W) /(T W-D W)] * 100
$$

where,

FW represents fresh weight,

TW is Turgid weight and

DW is Dry weight. 


\section{Electrolyte leakage}

For determination of electrolyte leakage (EL), 10 leaf discs of about $10 \mathrm{~mm}$ diameter from expanded leaves of all maize hybrids were taken and rinsed with distilled water to get rid of electrolytes adhered to the surface. These leaf discs were incubated at $10^{\circ} \mathrm{C}$ after placing them in glass tubes filled with $10 \mathrm{ml}$ of distilled water for $24 \mathrm{hr}$. The initial electrical conductivity (EC1) of the solution was measured using conductometer. To release all electrolytes, these tubes were heated at $95^{\circ} \mathrm{C}$ in water bath for $20 \mathrm{~min}$ followed by cooling at room temperature. After that final electrical conductivity (EC2) was determined.

EL was calculated using Equation 3 (Yildirim et al., 2009).

$$
E L=\left(\frac{E C 1}{E C 2}\right) * 100
$$

\section{Plant mineral ion contents}

For determination of mineral ions, $100 \mathrm{mg}$ of dried plant samples (roots and leaves) were heated for about $5 \mathrm{hrs}$ in furnace at $520^{\circ} \mathrm{C}$ for ash formation. The ash of each plant sample was then solubilized in nitric-perchloric acid mixture (5:1) and volume was raised to $15 \mathrm{ml}$ using distilled water. Afterwards filtered suspensions were used to determine the concentrations of $\mathrm{Na}^{+}, \mathrm{K}^{+}, \mathrm{Ca}^{+2}$ and $\mathrm{Mg}^{+2}$ using atomic absorption spectrometry. For standard curves, different concentrations of $\mathrm{Ca}^{+2}, \mathrm{~K}^{+}, \mathrm{Na}^{+}$and $\mathrm{Mg}^{+2}$ were prepared by diluting stock solution of $\mathrm{CaSO}_{4}, \mathrm{KCl}, \mathrm{NaCl}$ and $\mathrm{MgSO}_{4}$. The standard curve was used to determine the content of each element in the plant organs (roots and leaf) and expressed in $\mathrm{mg} \mathrm{g}^{-1} \mathrm{dw}$ (Qadir, 2016).

\section{Proline contents}

Leaf proline content was extracted and analyzed by the method of Bates et al. (1973). $0.1 \mathrm{~g}$ of fresh leaf of all maize hybrids were ground using liquid nitrogen in a mortar. $1 \mathrm{ml}$ of sulfosalicylic acid (3\% w/v) was added to the resulted homogenate powder of leaves and then filtered. The filtrate was reacted with $1 \mathrm{ml}$ of glacial acetic acid (GAA) and $1 \mathrm{ml}$ of ninhydrin reagent $\left(1.25 \mathrm{mg}\right.$ Ninhydrin in $30 \mathrm{ml}$ of GAA and $\left.20 \mathrm{ml} 6 \mathrm{M} \mathrm{H}_{3} \mathrm{PO}_{4}\right)$ and placed in an incubater for $1 \mathrm{hr}$ at $95^{\circ} \mathrm{C}$. To terminate the reaction, reaction mixture containing tubes were kept in ice bath for 5 min followed by vigorous mixing with $2 \mathrm{ml}$ toluene. After warming at $25^{\circ} \mathrm{C}$, the chromophore was measured at $520 \mathrm{~nm}$. L-proline was used as a standard.

\section{Statistical analysis}

For statistical analysis, results of all experiments were expressed as mean \pm standard deviation (SD) of three replicates. Data were subjected to one-way analysis of variance (ANOVA) and LSD multiple comparison test $(P<0.05)$ using the SPSS statistical package. Significant differences are indicated by alphabets in figures and tables.

\section{Results}

\section{Growth parameters of maize under salt stress and $\mathrm{Ca}^{2+}$ treatments}

The growth parameters of maize seedlings were evaluated by measuring leaf area, root length and shoot length of plants under salt stress. Effect of salt stress and calcium on 
growth parameters of five maize hybrids (CTRM8, PSEV2, SWAJ 6, 7, Syngenta 8441 and XPW3) are listed in Table 1. Under salt stress all five Maize hybrids react differently. Salt addition showed significant effect on growth parameters like leaf area, root length and shoot length of plants. The maximum decrease in these parameters was observed in CTRM 8 and XPW 3 whereas maximum shoot length, maximum root length and leaf area was exhibited by SWAJ 6, 7 and Syngenta 8441 which showed improved growth traits. However, effects of salinity were significantly alleviated in all five maize hybrids by foliar application of $2.5 \mathrm{mM} \mathrm{Ca}^{2+}$. Although application of $5 \mathrm{mM} \mathrm{Ca}^{2+}$ also improved plant growth but the effect was not significant as compare to $2.5 \mathrm{mM} \mathrm{Ca}^{2+}$ (Table 1).

Table 1. Shoot length $(\mathrm{cm})$, Root length $(\mathrm{cm})$, and Leaf area $\left(\mathrm{m}^{2}\right)$ concentration in leaves of all five Maize hybrids in response to salinity and $\mathrm{Ca}^{2+}$ concentrations

\begin{tabular}{|c|c|c|c|c|}
\hline Maize hybrid & Treatment & Shoot length & Root length & Leaf area \\
\hline \multirow{7}{*}{ CTRM8 } & T1 & $31.00 \mathrm{CD}$ & $21.33 \mathrm{G}$ & $21.85 \mathrm{IJ}$ \\
\hline & $\mathrm{T} 2$ & $22.68 \mathrm{I}$ & $17.00 \mathrm{IH}$ & $13.79 \mathrm{~L}$ \\
\hline & T3 & $32.50 \mathrm{C}$ & $19.83 \mathrm{H}$ & $27.55 \mathrm{D}$ \\
\hline & $\mathrm{T} 4$ & $30.33 \mathrm{D}$ & $15.67 \mathrm{I}$ & $25.72 \mathrm{~F}$ \\
\hline & T5 & $15.68 \mathrm{KL}$ & $13.33 \mathrm{~J}$ & $13.34 \mathrm{~L}$ \\
\hline & T6 & $30.17 \mathrm{D}$ & $17.17 \mathrm{IH}$ & $24.04 \mathrm{FG}$ \\
\hline & $\mathrm{T} 7$ & $24.00 \mathrm{G}$ & 11.83 & $17.23 \mathrm{~K}$ \\
\hline \multirow{7}{*}{ PSEV2 } & T1 & $33.50 \mathrm{BC}$ & $18.17 \mathrm{H}$ & $24.38 \mathrm{FG}$ \\
\hline & $\mathrm{T} 2$ & $22.67 \mathrm{H}$ & $16.17 \mathrm{I}$ & $18.55 \mathrm{IK}$ \\
\hline & $\mathrm{T} 3$ & $33.33 \mathrm{BC}$ & $21.50 \mathrm{G}$ & $26.58 \mathrm{E}$ \\
\hline & $\mathrm{T} 4$ & $30.00 \mathrm{E}$ & $18.33 \mathrm{H}$ & $25.09 \mathrm{~F}$ \\
\hline & $\mathrm{T} 5$ & $18.50 \mathrm{~K}$ & $12.67 \mathrm{~J}$ & $18.77 \mathrm{IK}$ \\
\hline & T6 & $32.00 \mathrm{D}$ & $16.17 \mathrm{I}$ & $25.96 \mathrm{EF}$ \\
\hline & $\mathrm{T} 7$ & $27.00 \mathrm{EF}$ & $8.17 \mathrm{M}$ & $18.19 \mathrm{IK}$ \\
\hline \multirow{7}{*}{ SWAJ 6, 7} & $\mathrm{~T} 1$ & $34.67 \mathrm{C}$ & $33.50 \mathrm{~A}$ & $26.46 \mathrm{E}$ \\
\hline & $\mathrm{T} 2$ & $28.17 \mathrm{~F}$ & $16.83 \mathrm{I}$ & $23.04 \mathrm{G}$ \\
\hline & T3 & $33.17 \mathrm{BC}$ & $32.50 \mathrm{~B}$ & $31.64 \mathrm{~B}$ \\
\hline & $\mathrm{T} 4$ & $31.00 \mathrm{CD}$ & $25.67 \mathrm{E}$ & $26.83 \mathrm{E}$ \\
\hline & T5 & $20.50 \mathrm{~J}$ & $17.67 \mathrm{H}$ & $18.86 \mathrm{IK}$ \\
\hline & T6 & $33.17 \mathrm{BC}$ & $27.00 \mathrm{D}$ & $25.24 \mathrm{~F}$ \\
\hline & $\mathrm{T} 7$ & $31.67 \mathrm{D}$ & $16.17 \mathrm{I}$ & $25.08 \mathrm{~F}$ \\
\hline \multirow{7}{*}{ Syngenta 8441} & $\mathrm{~T} 1$ & $38.17 \mathrm{~A}$ & $33.83 \mathrm{~A}$ & $28.88 \mathrm{CD}$ \\
\hline & $\mathrm{T} 2$ & $27.00 \mathrm{EF}$ & $25.57 \mathrm{E}$ & $26.06 \mathrm{E}$ \\
\hline & $\mathrm{T} 3$ & $37.00 \mathrm{AB}$ & $32.67 \mathrm{~B}$ & $33.26 \mathrm{~A}$ \\
\hline & $\mathrm{T} 4$ & $33.50 \mathrm{BC}$ & $23.33 \mathrm{~F}$ & $30.14 \mathrm{BC}$ \\
\hline & $\mathrm{T} 5$ & $23.83 \mathrm{GH}$ & $26.67 \mathrm{DE}$ & $23.63 \mathrm{G}$ \\
\hline & T6 & $33.67 \mathrm{CD}$ & $21.00 \mathrm{G}$ & $29.67 \mathrm{C}$ \\
\hline & $\mathrm{T} 7$ & $36.17 \mathrm{~B}$ & $28.83 \mathrm{C}$ & $27.75 \mathrm{D}$ \\
\hline \multirow{7}{*}{ XPW3 } & $\mathrm{T} 1$ & $27.00 \mathrm{EF}$ & $26.50 \mathrm{DE}$ & $21.85 \mathrm{H}$ \\
\hline & $\mathrm{T} 2$ & $24.83 \mathrm{H}$ & 14.50 & $17.08 \mathrm{~K}$ \\
\hline & $\mathrm{T} 3$ & $29.33 \mathrm{DE}$ & $18.67 \mathrm{H}$ & $22.74 \mathrm{GH}$ \\
\hline & $\mathrm{T} 4$ & $25.33 \mathrm{FG}$ & $14.17 \mathrm{~K}$ & $22.35 \mathrm{GH}$ \\
\hline & $\mathrm{T} 5$ & $15.83 \mathrm{KL}$ & $13.00 \mathrm{~K}$ & $14.93 \mathrm{KL}$ \\
\hline & T6 & $26.67 \mathrm{G}$ & $14.33 \mathrm{~K}$ & $20.13 \mathrm{IJ}$ \\
\hline & $\mathrm{T} 7$ & $24.17 \mathrm{H}$ & $12.67 \mathrm{~L}$ & $19.55 \mathrm{I}$ \\
\hline
\end{tabular}

Mean values followed by different letters within each column differ significantly at $P \leq 0.05$. T1: Control (non- saline); T2: $75 \mathrm{mM} \mathrm{NaCl}$; T3: $75 \mathrm{mM} \mathrm{NaCl}+2.5 \mathrm{mM} \mathrm{Ca}^{2+}$; T4: $75 \mathrm{mM} \mathrm{NaCl}+5 \mathrm{mM} \mathrm{Ca}^{2+}$; T5: $150 \mathrm{mM} \mathrm{NaCl}$; T6: $150 \mathrm{mM} \mathrm{NaCl}+2.5 \mathrm{mM} \mathrm{Ca}^{2+}$; 7 : $150 \mathrm{mM} \mathrm{NaCl}+2.5 \mathrm{mM} \mathrm{Ca}^{2+}$ 


\section{Leaf chlorophyll content in maize under salt stress and $\mathrm{Ca}^{2+}$ treatments}

Salt stress showed significant effect on total leaf chlorophyll contents of maize hybrids. Increase in salt stress resulted decrease in chlorophyll contents of maize leaves. It is found from the results that the high levels of salinity $(150 \mathrm{mM} \mathrm{NaCl})$ induced reduction in the total chlorophyll contents of leaves significantly in comparison to leaves of control plants. However, $\mathrm{Ca}^{2+}$ application on plants under salt stress increased the leaf chlorophyll contents (Table 2). Importantly, $2.5 \mathrm{mM} \mathrm{Ca}^{2+}$ treatments showed significantly higher total chlorophyll contents compared to that of $5 \mathrm{mM} \mathrm{Ca}^{2+}$ treatments.

Table 2. Total leaf chlorophyll contents ( $\left.\mathrm{mg}^{-1} \mathrm{FW}\right), \mathrm{RWC}(\%)$, and Electrolyte leakage (\%) concentration in leaves of all five Maize hybrids in response to salinity and $\mathrm{Ca}^{2+}$ concentrations

\begin{tabular}{|c|c|c|c|c|}
\hline Maize hybrid & Treatment & $\begin{array}{l}\text { Total chlorophyll } \\
\left(\mathrm{mg} \mathrm{g}^{-1} \text { FW) }\right.\end{array}$ & $\begin{array}{c}\text { Relative water } \\
(\%)\end{array}$ & \begin{tabular}{|c}
$\begin{array}{c}\text { Electrolyte leakage } \\
(\%)\end{array}$ \\
\end{tabular} \\
\hline \multirow{7}{*}{ CTRM8 } & $\mathrm{T} 1$ & $15.19 \mathrm{C}$ & $77.09 \mathrm{I}$ & $22.61 \mathrm{R}$ \\
\hline & $\mathrm{T} 2$ & $9.42 \mathrm{~F}$ & $72.32 \mathrm{~J}$ & $61.67 \mathrm{D}$ \\
\hline & $\mathrm{T} 3$ & $13.58 \mathrm{D}$ & $86.60 \mathrm{D}$ & $33.93 \mathrm{~N}$ \\
\hline & $\mathrm{T} 4$ & $11.80 \mathrm{E}$ & $80.56 \mathrm{H}$ & $29.61 \mathrm{P}$ \\
\hline & T5 & $6.79 \mathrm{G}$ & 60.14 & $68.63 \mathrm{~A}$ \\
\hline & T6 & $10.88 \mathrm{EF}$ & $78.73 \mathrm{I}$ & $65.26 \mathrm{~B}$ \\
\hline & $\mathrm{T} 7$ & $10.35 \mathrm{EF}$ & $59.60 \mathrm{~N}$ & $63.15 \mathrm{C}$ \\
\hline \multirow{7}{*}{ PSEV2 } & $\mathrm{T} 1$ & $17.73 \mathrm{~B}$ & $84.34 \mathrm{E}$ & $25.33 \mathrm{Q}$ \\
\hline & $\mathrm{T} 2$ & $12.01 \mathrm{DE}$ & $70.14 \mathrm{~K}$ & $58.54 \mathrm{E}$ \\
\hline & $\mathrm{T} 3$ & $15.79 \mathrm{C}$ & $96.34 \mathrm{~A}$ & $36.33 \mathrm{M}$ \\
\hline & $\mathrm{T} 4$ & $13.55 \mathrm{D}$ & $79.25 \mathrm{H}$ & $32.33 \mathrm{~N}$ \\
\hline & T5 & $8.51 \mathrm{~F}$ & $61.26 \mathrm{M}$ & $63.33 \mathrm{C}$ \\
\hline & T6 & $13.43 \mathrm{D}$ & $77.16 \mathrm{I}$ & $61.33 \mathrm{D}$ \\
\hline & $\mathrm{T} 7$ & $14.06 \mathrm{CD}$ & $65.67 \mathrm{~L}$ & $59.33 \mathrm{E}$ \\
\hline \multirow{7}{*}{ SWAJ 6, 7} & $\mathrm{~T} 1$ & $19.38 \mathrm{~A}$ & $90.85 \mathrm{C}$ & $20.00 \mathrm{~S}$ \\
\hline & $\mathrm{T} 2$ & $13.16 \mathrm{D}$ & $73.05 \mathrm{~J}$ & $46.39 \mathrm{~K}$ \\
\hline & $\mathrm{T} 3$ & $16.26 \mathrm{BC}$ & $93.31 \mathrm{~B}$ & $31.00 \mathrm{O}$ \\
\hline & $\mathrm{T} 4$ & $14.45 \mathrm{CD}$ & $85.85 \mathrm{E}$ & $27.53 \mathrm{Q}$ \\
\hline & T5 & $10.56 \mathrm{EF}$ & $61.81 \mathrm{M}$ & $56.27 \mathrm{~F}$ \\
\hline & $\mathrm{T} 6$ & $15.10 \mathrm{C}$ & $81.84 \mathrm{G}$ & $49.38 \mathrm{I}$ \\
\hline & $\mathrm{T} 7$ & $13.59 \mathrm{D}$ & $72.01 \mathrm{~J}$ & $46.05 \mathrm{~K}$ \\
\hline \multirow{7}{*}{ Syngenta 8441} & $\mathrm{~T} 1$ & $19.60 \mathrm{~A}$ & $93.68 \mathrm{~B}$ & $19.32 \mathrm{~S}$ \\
\hline & $\mathrm{T} 2$ & $13.68 \mathrm{D}$ & $80.27 \mathrm{H}$ & $45.21 \mathrm{~L}$ \\
\hline & $\mathrm{T} 3$ & 16.63 BC & $96.76 \mathrm{~A}$ & $30.32 \mathrm{P}$ \\
\hline & $\mathrm{T} 4$ & $14.99 \mathrm{CD}$ & $86.05 \mathrm{D}$ & $26.42 \mathrm{Q}$ \\
\hline & $\mathrm{T} 5$ & $11.75 \mathrm{E}$ & $68.34 \mathrm{~L}$ & $55.15 \mathrm{G}$ \\
\hline & T6 & $14.40 \mathrm{CD}$ & $81.66 \mathrm{G}$ & $48.00 \mathrm{~J}$ \\
\hline & $\mathrm{T} 7$ & $15.40 \mathrm{C}$ & $67.06 \mathrm{~L}$ & $45.00 \mathrm{~L}$ \\
\hline \multirow{7}{*}{ XPW3 } & $\mathrm{T} 1$ & $17.46 \mathrm{~B}$ & $85.25 \mathrm{D}$ & $23.08 \mathrm{R}$ \\
\hline & $\mathrm{T} 2$ & $10.51 \mathrm{EF}$ & $65.67 \mathrm{~L}$ & $59.68 \mathrm{E}$ \\
\hline & $\mathrm{T} 3$ & $14.97 \mathrm{C}$ & $89.66 \mathrm{C}$ & $33.74 \mathrm{~N}$ \\
\hline & $\mathrm{T} 4$ & $14.42 \mathrm{CD}$ & $85.29 \mathrm{D}$ & $30.26 \mathrm{P}$ \\
\hline & $\mathrm{T} 5$ & $6.53 \mathrm{G}$ & 49.77 P & $69.83 \mathrm{~A}$ \\
\hline & $\mathrm{T} 6$ & $9.93 \mathrm{~F}$ & $83.82 \mathrm{~F}$ & $51.43 \mathrm{H}$ \\
\hline & $\mathrm{T} 7$ & $8.38 \mathrm{~F}$ & $54.29 \mathrm{O}$ & $59.80 \mathrm{E}$ \\
\hline
\end{tabular}

Mean values followed by different letters within each column differ significantly at $P \leq 0.05$. T1: Control (non-saline); T2: $75 \mathrm{mM} \mathrm{NaCl}$; T3: $75 \mathrm{mM} \mathrm{NaCl}+2.5 \mathrm{mM} \mathrm{Ca}^{2+}$; T4: $75 \mathrm{mM} \mathrm{NaCl}+5 \mathrm{mM} \mathrm{Ca}^{2+}$; T5: $150 \mathrm{mM} \mathrm{NaCl}$; 6 : $150 \mathrm{mM} \mathrm{NaCl}+2.5 \mathrm{mM} \mathrm{Ca}^{2+} ; \mathrm{T} 7: 150 \mathrm{mM} \mathrm{NaCl}+2.5 \mathrm{mM} \mathrm{Ca}^{2+}$ 


\section{$R W C$ of maize under salt stress and $\mathrm{Ca}^{2+}$ treatments}

Salt stress significantly reduced RWC in all maize hybrids with more prominent effect in CTRM8 and XPW3 in comparison with the control conditions. Salt-induced water imbalance resulted in decrease RWC. However, foliar application of $2.5 \mathrm{mM}$ and $5 \mathrm{mM}$ $\mathrm{Ca}^{2+}$ on salt-stressed maize plants increased RWC significantly in comparison to plants under salt stress only (Table 2).

\section{Electrolyte leakage under salt stress and $\mathrm{Ca}^{2+}$ treatments}

The increasing salt concentrations enhanced EL value of all maize hybrids (Table 2). The highest EL was observed in CTRM 8 and XPW3 in comparison to SWAJ 6, 7 and Syngenta 8441 under all stress conditions. However, supplemented $\mathrm{Ca}^{2+}$ reduced MP of salt stressed plants compared to plants without $\mathrm{Ca}^{2+}$ under salt stress. The application of $\mathrm{Ca}^{2+}$ significantly improved MP by decreasing the electrolyte leakage under salt stress.

\section{$\mathrm{Na}, \mathrm{K}^{+}, \mathrm{Ca}$ and $\mathrm{Mg}$ contents of leaves and roots under salt stress and $\mathrm{Ca}^{2+}$ treatments}

Salinity has very clear effects on ionic composition of maize. Maize genotype SWAJ 6, 7 and Syngenta 8441 showed better chemical attributes at all levels of salt stress. In all five maize hybrids, $\mathrm{Na}^{+}$accumulation in leaves and roots was proportional to the $\mathrm{NaCl}$ concentration in the medium applied exogenously. Significant increase of $\mathrm{Na}^{+}$ levels was found in roots and leaves of all maize hybrids under treatments. This increase was more obvious in the leaves of XPW 3 than that in SWAJ 6, 7 and Syngenta 8441 hybrids (Fig. 1a). The highest concentration of $\mathrm{Na}^{+}$were observed in the roots of SWAJ 6, 7 and Syngenta 8441 at $150 \mathrm{mM} \mathrm{NaCl}$ treatment in combination with 2.5 and $5 \mathrm{mM}$ foliar $\mathrm{Ca}^{2+}$ applications (Fig. 1b). Sodium accumulation in roots and leaves of maize hybrids under combined treatment of $\mathrm{NaCl}+\mathrm{Ca}^{2+}$ was found less than sodium in plants under treatment of $\mathrm{NaCl}$ alone. $\mathrm{Ca}^{2+}$ application thus alleviates the hyperaccumulation of $\mathrm{Na}^{+}$ions in plants under salt stress (Fig. la,b).
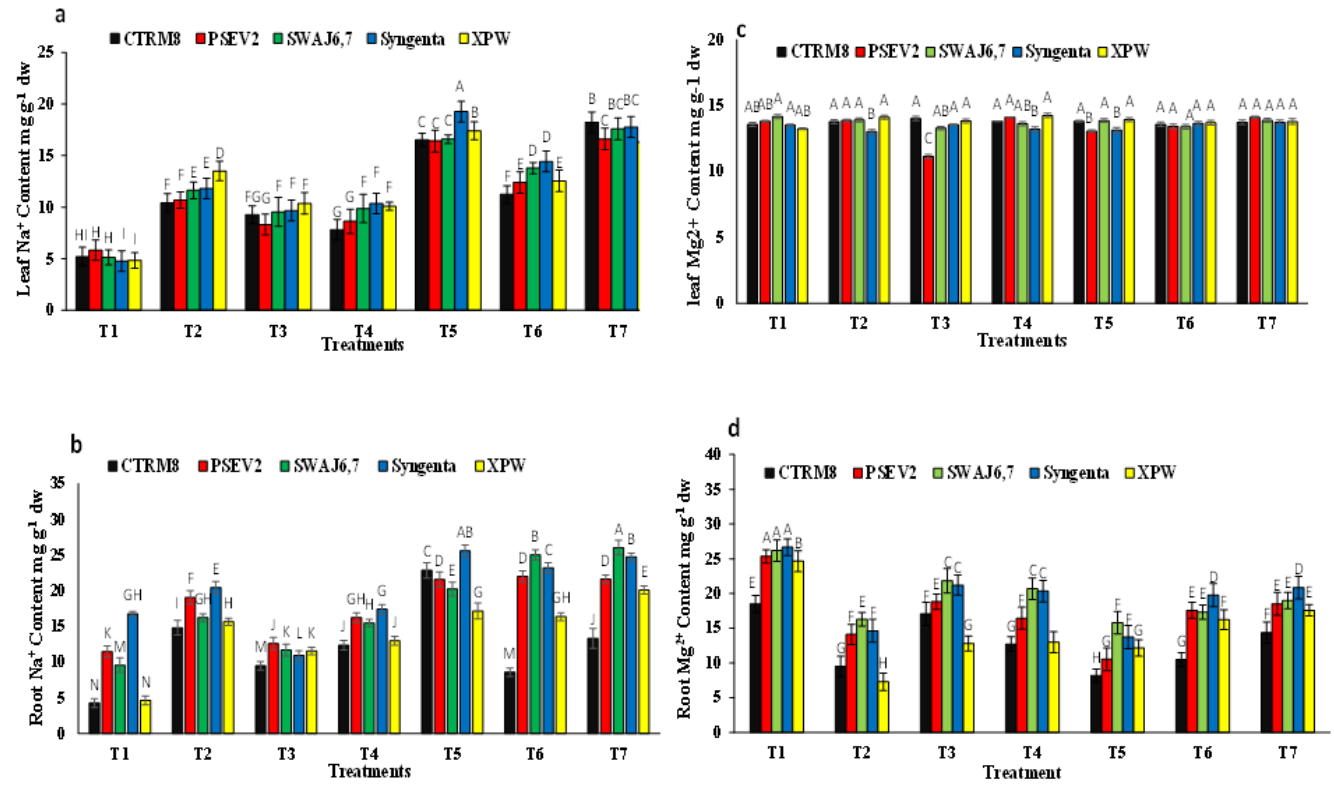

Figure 1. The Na concentration of leaf (a) and root (b) Mg concentration of leaf (c) and root (d) of five maize hybrids (CTRM8, PSEV2, SWAJ 6, 7, Syngenta 8441, XPE3) in response to salinity and $\mathrm{Ca}^{2+}$ supplement. Values are means $\pm S E$ of three replicates 
$\mathrm{Mg}^{2+}$ content of leaf showed no significant effect under salt stress and foliar application of $\mathrm{Ca}^{2+}$ under salinity did not change the $\mathrm{Mg}^{2+}$ contents in leaf (Fig. 1c). However, salinity showed negative effect on root $\mathrm{Mg}^{2+}$ contents. Foliar $\mathrm{Ca}^{2+}$ application enhanced concentration of $\mathrm{Mg}$ in roots of all maize hybrids under salt stress (Fig. 1d).

Salt stress had induced noticeable variations in $\mathrm{Ca}^{2+}$ and $\mathrm{K}^{+}$contents in leaves and roots of all maize hybrids. In comparison to that of control plants, all five maize hybrids showed decline in $\mathrm{K}^{+}$and $\mathrm{Ca}^{2+}$ contents of roots and leaves under salt stress. This decrease in $\mathrm{K}^{+}$and $\mathrm{Ca}^{2+}$ was more pronounced in CTRM8 and XPW3 as compared to SWAJ 6, 7 and Syngenta 8441 maize hybrids. Supplemental $\mathrm{Ca}^{2+}$ enhanced the $\mathrm{K}^{+}$and $\mathrm{Ca}^{2+}$ concentrations of leaves and roots of maize plants under salt stress. At all salinity levels, maintenance of high level of $\mathrm{K}^{+}$was better in SWAJ 6, 7 and Syngenta 8441 in comparison to CTRM8 and XPW3 (Fig. 2).
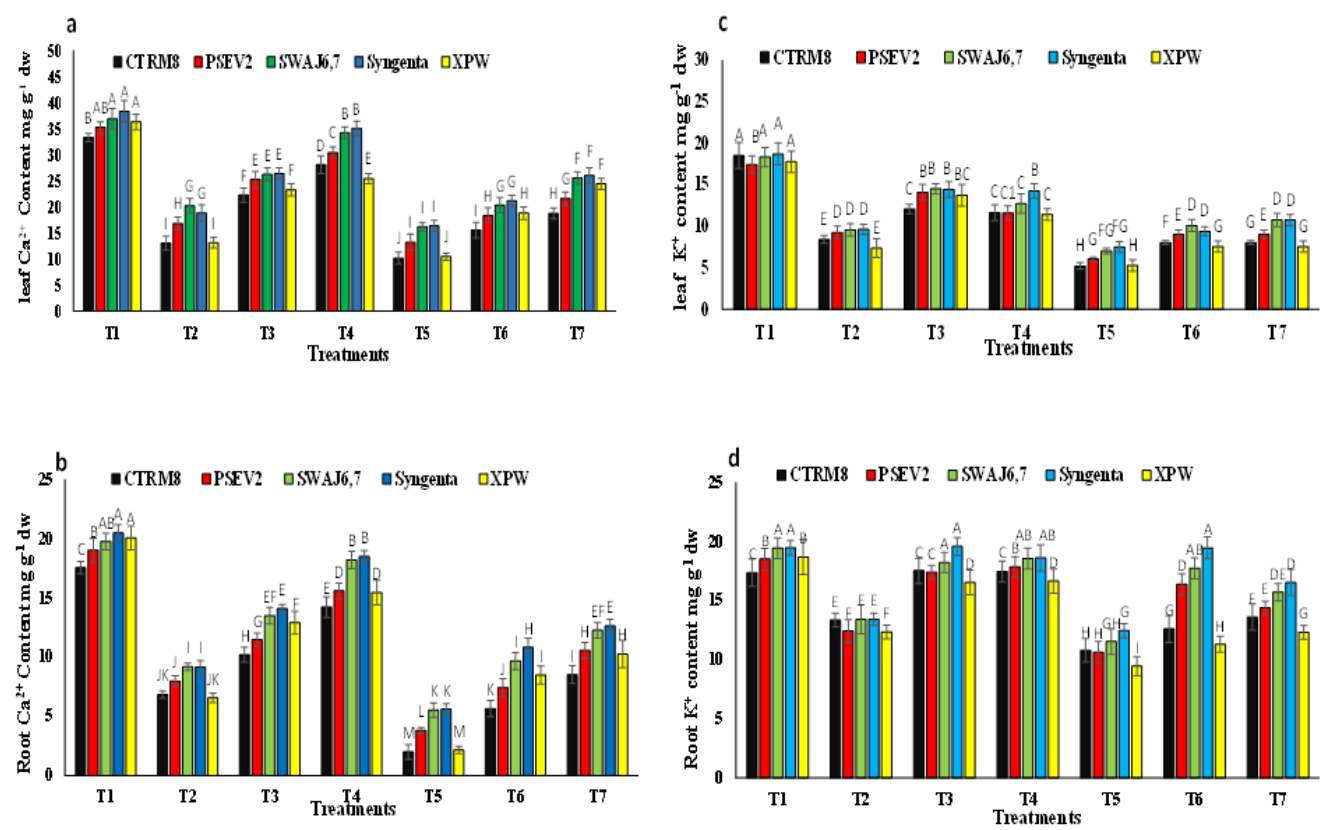

Figure 2. The Ca concentration of leaf (a) and root (b) K concentration of leaf (c) and root (d) of five maize hybrids (CTRM8, PSEV2, SWAJ 6, 7, Syngenta 8441, XPE3) in response to salinity and $\mathrm{Ca}^{2+}$ supplement. Values are means \pm SE of three replicates

For all five maize hybrids, $\mathrm{Na}^{+} / \mathrm{K}^{+}$ratio increased dramatically under salt stress with more notable effect in leaves of CTRM8 and XPW3 (Fig. 3). Supplemental $\mathrm{Ca}^{2+}$ resulted significant decline in $\mathrm{Na}^{+} / \mathrm{K}^{+}$ratio of maize leaves under salt stress.

\section{Proline contents of maize leaves under salt stress and $\mathrm{Ca}^{2+}$ treatments}

Analysis of proline contents of maize leaves indicated that application of salt resulted in increased proline contents in all maize hybrids with more pronounced effect in CTRM8 and XPW3 as compare to SWAJ 6, 7 and Syngenta 8441. Under salt stress, proline contents in maize enhanced significantly (Fig. 4). However, proline concentration was markedly decreased in plants with exogenous application of $2.5 \mathrm{mM}$ and $5 \mathrm{mM}$ concentrations of $\mathrm{Ca}^{2+}$ under salt stress. The less proline contents were found in plants treated with $2.5 \mathrm{mM} \mathrm{Ca}^{2+}$. 

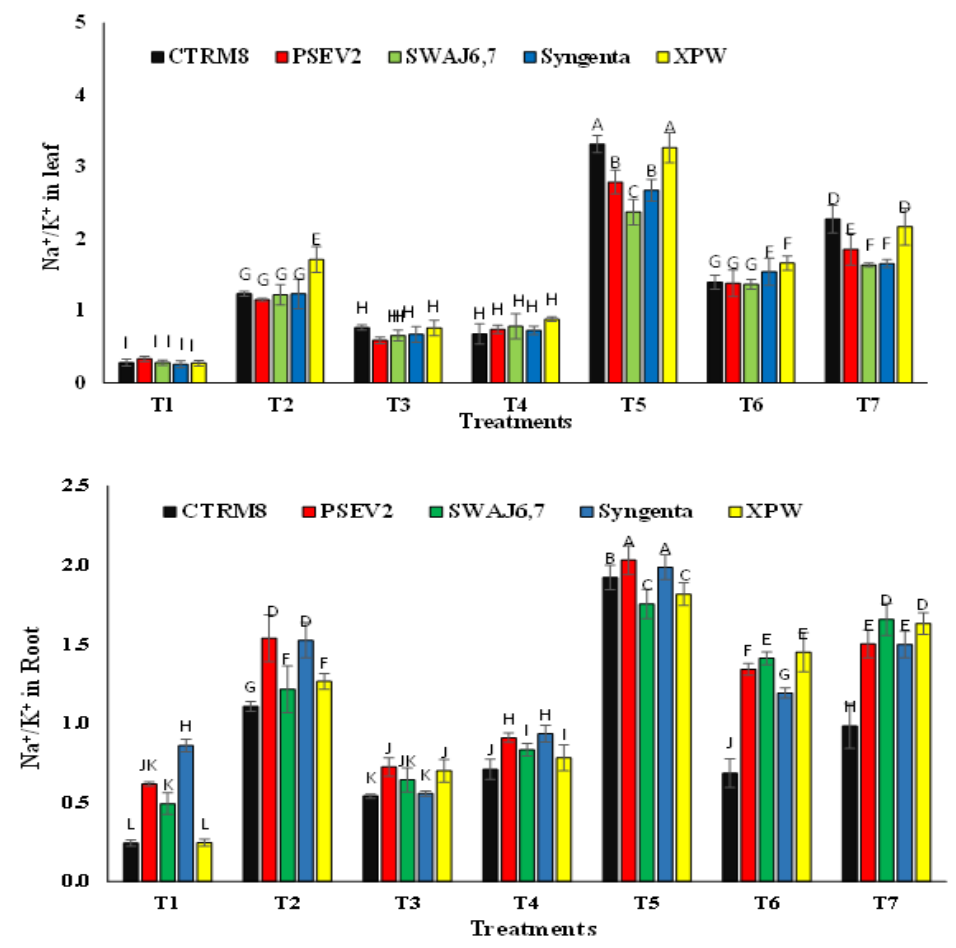

Figure 3. The Na/K Ratio in roots (a) and leaf (b) of leaf of five maize hybrids (CTRM8, PSEV2, SWAJ 6, 7, Syngenta 8441, XPE3) in response to salinity and $\mathrm{Ca}^{2+}$ supplement. Values are means $\pm S E$ of three replicates

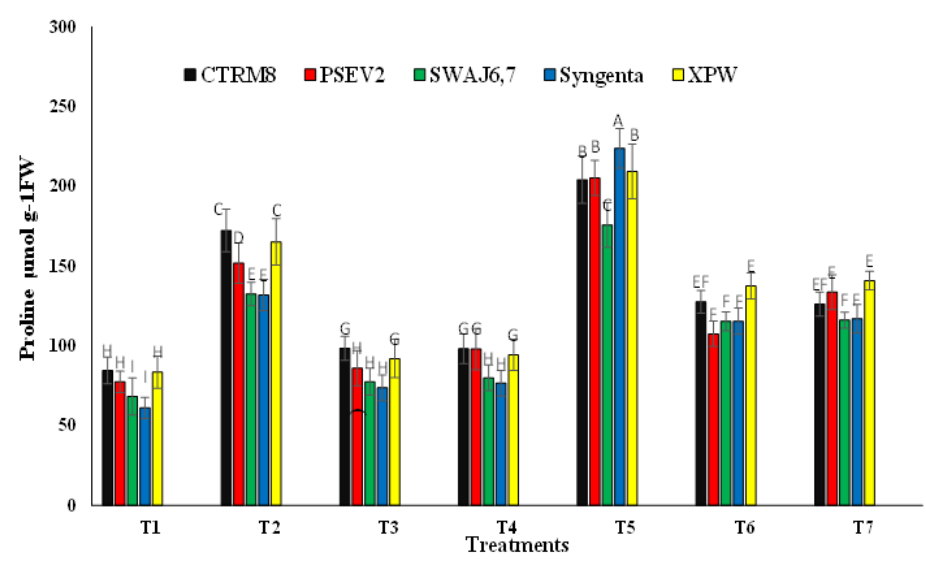

Figure 4. Proline content of of five maize hybrids (CTRM8, PSEV2, SWAJ 6, 7, Syngenta 8441, $X P E 3)$ in response to salinity and $\mathrm{Ca}^{2+}$ supplement. Values are means $\pm S E$ of three replicates

\section{Discussion}

The current study was carried out to investigate the genetic variation of five maize hybrids against salt stress in combination with exogenous application of calcium $\left(\mathrm{Ca}^{2+}\right)$. The decrease in plant growth parameters such as shoot length, root length, leaf area, plant weight (fresh and dry) due to salt stress, confirming many prior findings (Mulholland, 2002; Yurtseven et al., 2003; Agong et al., 2004; Ahmad, 2012). Excessive $\mathrm{Na}^{+}$ accumulation in presence of $\mathrm{NaCl}$ resulted in nutritional and metabolic imbalances due 
to ion toxicity which led to reduction in growth parameters of maize hybrids. It was reported that higher accumulation of $\mathrm{Na}^{+}$ions is the main cause of decreased plant growth and metabolism (Zhu, 2002). The genotypes with less concentration of $\mathrm{Na}^{+}$produced more biomass as confirmed by Munns and James (2003).

$\mathrm{Ca}^{2+}$ ion shows ameliorating effect on growth parameters of plants under salt stress may be by competing with $\mathrm{Na}^{+}$ion for binding with membranes. $\mathrm{Ca}^{2+}$ application minimized the harmful effects of $\mathrm{NaCl}$ and enhanced plant growth of all five maize hybrids. Previous studies also reported that exogenous $\mathrm{Ca}^{2+}$ application increased plant growth and tolerance to salt stress in Cassia angustifolia (Senna) (Arshi et al., 2005), Eleusine coracana (finger millet), Thinopyrum ponticum (wheatgrass) and Lolium perenne (ryegrass) (Sima et al., 2009), Cakile maritime (Sea Rocket) (Amor et al., 2010), Zea mays (Maize) (Shoresh et al., 2011), Cunninghamia Lanceolata (Chinese fir) (Liu et al., 2014), Lycopersicon esculentum (Tomato) (Parvin et al., 2015) and Calligonum mongolicum (Xu et al., 2017). Ameliorative effect of calcium by enhancing the vegetative growth and total dry weight of plants under salt stress has also been confirmed by Manivannan et al. (2007). Improved growth performance of SWAJ 6, 7 and Syngenta 8441 under salt stress indicate that these maize hybrids are more tolerant to salinity stress than CTRM8, PSEV2 and XPW3.

Salt stress showed significant effect on total leaf chlorophyll contents of maize hybrids. Increase in salt stress resulted decrease in chlorophyll contents of maize leaves. It is found from the results that the high levels of salinity $(150 \mathrm{mM} \mathrm{NaCl})$ induced reduction in the total chlorophyll contents of leaves significantly in comparison to leaves of control plants. Netondo et al. (2004), Amini and Ehsanpour (2006) and Naher (2014) also reported similar findings. Moreover, chlorophyll contents were less affected in SWAJ 6, 7 and Syngenta 8441 than CTRM8 and XPW3 indicated that they were able to maintain photosynthetic capacity under salt stress. However, $\mathrm{Ca}^{2+}$ application on plants under salt stress increased the leaf chlorophyll contents (Table 2). A range of plant species responses from positive to negative effects to supplemental $\mathrm{Ca}^{2+}$ have been described in previous studies (Cramer, 2002; Cabot et al., 2009). Nevertheless, total leaf chlorophyll significantly increased by supplemental $\mathrm{Ca}^{2+}$ under salt stress (Table 2). Similar responses were found in other plants such as Cucumis sativus L. (Cucumber), Fragaria ananassa (strawberry) and Vigna radiate (Mung bean) (Kaya and Higgs, 2002; Kaya et al., 2002; Manivannan et al., 2007). Importantly, $2.5 \mathrm{mM} \mathrm{Ca}^{2+}$ treatments showed significantly higher total chlorophyll contents compared to that of $5 \mathrm{mM} \mathrm{Ca}^{2+}$ treatments.

Reduction in RWC in salt stressed plant is a common phenomenon. In present study all five maize hybrids showed decreased RWC under salt stress with less significant effect under mild stress of $75 \mathrm{mM} \mathrm{NaCl}$ in Syngenta 8441 and SWAJ 6, 7. Similar water shortage induced by salt was observed in Oryza sativa and Zea mays affected with salt (Cicek and Cakirlar, 2002; Tuna et al., 2008). Plants supplemented with $\mathrm{Ca}^{2+}$ showed improved RWC may be due to water retention under salt stress. Similar results were reported by Tahjib-Ul-Arif et al., (2018).

Membrane permeability (MP) can be determined by measuring electrolyte leakage (EL). Plasma membranes are primarily affected by ion-specific salt injury (Mansour et al., 2005). Hence, for the identification of salt tolerant plants, determination of electrolyte leakage from plasma membranes is an important criterion (Ashraf and Ali, 2008). In present study, all maize hybrids showed increase in EL under salt stress which is an indication of membrane dysfunction. The increased permeability of cellular membranes for electrolytes and ions is the clear indication of membrane dysfunction caused by salt 
stress and it can be measured by the electrolytes and efflux (Qadir, 2016). The highest EL was observed in CTRM 8 and XPW3 in comparison to SWAJ 6, 7 and Syngenta 8441. Demidchik et al. (2014) stated that efflux of $\mathrm{K}^{+}$is mainly related to electrolyte leakage. However, supplemented $\mathrm{Ca}^{2+}$ reduced MP of salt stressed plants compared to plants without $\mathrm{Ca}^{2+}$ under salt stress. The application of $\mathrm{Ca}^{2+}$ significantly improved MP by decreasing the electrolyte leakage under salt stress.

Salinity has very clear effects on ionic composition of maize. Significant increase of $\mathrm{Na}^{+}$levels was found in roots and leaves of all maize hybrids under treatments. This increase was more obvious in the leaves of XPW 3 than that in SWAJ 6, 7 and Syngenta 8441 hybrids (Fig. 1a). The highest concentration of $\mathrm{Na}^{+}$were observed in the roots of SWAJ 6, 7 and Syngenta 8441 at $150 \mathrm{mM} \mathrm{NaCl}$ treatment (Fig. 1b). Similar response was also reported in other plants such as Malus species, Myrtus Communis L. (Myrtle), Citrus and Pistacia vera (Pistachio) (Liu et al., 2012; Acosta-Motos et al., 2015; Martínez-Alcántara et al., 2015; Rahneshan et al., 2018).

Salt stress had induced noticeable variations in $\mathrm{Ca}^{2+}$ and $\mathrm{K}^{+}$contents in leaves and roots of all maize hybrids. In comparison to that of control plants, all five maize hybrids showed decline in $\mathrm{K}^{+}$and $\mathrm{Ca}^{2+}$ contents of roots and leaves under salt stress. This decrease in $\mathrm{K}^{+}$and $\mathrm{Ca}^{2+}$ was more pronounced in CTRM8 and XPW3 as compared to SWAJ 6, 7 and Syngenta 8441 maize hybrids. Supplemental $\mathrm{Ca}^{2+}$ enhanced the $\mathrm{K}^{+}$and $\mathrm{Ca}^{2+}$ concentrations of leaves and roots of maize plants under salt stress, similar to findings in other plant species (Tuna et al., 2007; Nedjimi and Daoud, 2009; Cabot et al., 2009; Kwon et al., 2009). At all salinity levels, maintenance of high level of $\mathrm{K}^{+}$was better in SWAJ 6, 7 and Syngenta 8441 in comparison to CTRM8 and XPW3 (Figure 2).

Increase in salinity levels lead to increased uptake of $\mathrm{Na}^{+}$which dramatically increased $\mathrm{Na}^{+} / \mathrm{K}^{+}$ratio in roots and leaves of all maize hybrids. For all five maize hybrids, $\mathrm{Na}^{+} / \mathrm{K}^{+}$ ratio increased dramatically under salt stress with more notable effect in leaves of CTRM8 and XPW3 (Fig. 3). Supplemental $\mathrm{Ca}^{2+}$ resulted significant decline in $\mathrm{Na}^{+} / \mathrm{K}^{+}$ratio of maize leaves under salt stress. It is documented that in salt-stressed plants, $\mathrm{Ca}^{2+}$ sustains $\mathrm{K}^{+} / \mathrm{Na}^{+}$selectivity and $\mathrm{K}^{+}$transport at the plasma membrane. Exogenous $\mathrm{Ca}^{2+}$ can reduce $\mathrm{K}^{+}$loss and enhance its uptake in plants under salt stress by affecting different channels as demonstrated by several previous studies (Shabala and Newman, 2000; Maathuis and Sanders, 2001; Shabala et al., 2003, 2005, 2006). This indicates that $\mathrm{Ca}^{2+}$ amelioration of salt stress is a critical process in $\mathrm{K}^{+}$transport regulation that may induce growth in plants. Better chemical attributes of SWAJ 6, 7 and Syngenta 8441 at all levels of salt stress could be the reason of their tolerance to salt stress.

Proline is considered as a source of nitrogen and carbon for rapid recovery of plants under salt stress. It acts as free radical scavenger and not only adjust the osmotic pressure of plant but also found to involve in stabilization of membranes and some macromolecules in plant cells. Less accumulation of proline contents in salt stressed maize seedlings treated with calcium shows protective role of calcium in plants by reducing osmotic pressure caused by salt stress (Hoque et al., 2007). Therefore, plants accumulated less proline contents under salt stress with application of calcium. Accumulation of proline is the primary defense response in many plants under salt stress to adjust the osmotic potential as reported in various salt sensitive/ tolerant cultivars such as Zea mays (Maize), Vigna radiate (Mung bean), Sesamum indicum (sesame), Setaria italica L. (foxtail millet) and Pistacia vera (Pistachio) (Mansour et al., 2005; Misra and Gupta, 2005; Koca et al., 2007; Veeranagamallaiah et al., 2007; Chelli-Chaabouni et al., 2010). Some studies showed that under salt stress, tolerant 
cultivars accumulate more proline than the salt sensitive cultivars (Misra and Gupta, 2005; Rahneshan et al., 2018). However, proline accumulation is also controversial with reference to tolerance and osmotic adjustment in plants exposed to undesirable environmental conditions (Ghars et al., 2008) as indicated by some studies where more proline accumulated in salt sensitive cultivars than the salt tolerant cultivar (Claussen, 2005). In current study proline accumulation was significantly higher in maize hybrids evaluated as salt sensitive (CTRM8 and XPW3) than in salt tolerant (SWAJ 6, 7 and Syngenta 8441). These results suggest that loss of cell homeostasis is responsible for excessive proline accumulation in salt sensitive hybrids. Similar results have been reported in previous studies where salt sensitive genotype of Sorghum bicolor L. (Sorghum kaya) (Wheat Arta) (Akbari et al., 2016) accumualted more proline under salt stress. These findings indicate that more proline accumulation is due to loss of cell homoeostasis. Moreover, these results suggest that salt tolerance is not fully reflected by proline accumulation itself in plants; however, proline accumulation could be an indicator of stress.

\section{Conclusion}

The overall results indicate that the growth parameters of all five maize hybrids were affected significantly by different salt stresses. However, better growth performance, maintenance of nutrient contents, less accumulation of toxic sodium ions and lower $\mathrm{Na}^{+} / \mathrm{K}^{+}$in SWAJ 6, 7 and Syngenta 8441 indicate that these maize hybrids are more tolerant to salinity stress than all others. It is also concluded that the foliar application of $\mathrm{Ca}^{2+}$ against salt stresses improved the growth parametrs of hybrids. Therefore, it can be concluded that the salt stress can be mitigated by the exogenous application of $\mathrm{Ca}^{2+}$ in crop plants. Further, the experiment might be repeated in different locations with different maize hybrids for making concrete recommendations.

Acknowledgements. We are grateful to Dr. Mohammad Asif from department of Management Sciences COMSATS University Islamabad for his assistance during statistical analysis of the data. This article is a contribution from the Department of Biotechnology, COMSATS University Islamabad, Abbottabad Campus.

\section{REFERENCES}

[1] Acosta-Motos, J. R., Diaz-Vivancos, P., Álvarez, S., Fernández-García, N., SánchezBlanco, M. J., Hernández, J. A. (2015): NaCl-induced physiological and biochemical adaptative mechanisms in the ornamental Myrtus communis L. plants. - Journal of Plant Physiology 183: 41-51.

[2] Agong, S. G., Yoshida, Y., Yazawa, S., Masuda, M. (2004): Tomato response to salt stress. - Acta Horticulturae 637: 93-97.

[3] Ahmad, K., Saqib, M., Akhtar, J., Ahmad, R. (2012): Evaluation and characterization of genetic variation in maize (Zea mays L.) for salinity tolerance. - Pakistan Journal of Agricultural Sciences 49: 521-526.

[4] Akbari, M., Toorchi, M., Shakiba, M. R. (2016): The Effects of Sodium Chloride Stress on Proline Content and Morphological Characteristics in Wheat (Triticum aestivum L.). Biological Forum 8(1): 379-385. 
[5] Amini, F., Ehsanpour, A. A. (2006): Response of tomato (Lycopersicon esculentum Mill.) cultivars to MS, water agar and salt stress in in vitro culture. - Pakistan Journal of Biological Sciences 9: 170-175.

[6] Amor, N. B., Megdiche, W., Jiménez, A., Sevilla, F., Abdelly, C. (2010): The effect of calcium on the antioxidant systems in the halophyte Cakile maritima under salt stress. Acta Physiologiae Plantarum 32: 453-461.

[7] Arshi, A., Abdin, M. Z., Iqbal, M. (2005): Ameliorative Effects of $\mathrm{CaCl}_{2}$ on Growth, Ionic Relations, and Proline Content of Senna Under Salinity Stress. - Journal of Plant Nutrition 28: 101-125.

[8] Ashraf, M., Ali, Q. (2008): Relative membrane permeability and activities of some antioxidant enzymes as the key determinants of salt tolerance in canola (Brassica napus L.). - Environmental and Experimental Botany 63: 266-273.

[9] Bates, C. P., Loose, H., Stanton, J. L. (1973): The objective study of incontinence after repair operations. - Surgery Gynecology and Obstetrics 136: 17-22.

[10] Cabot, C., Sibole, J. V., Barcelo, J., Poschenrieder, C. (2009): Sodium-calcium interactions with growth, water, and photosynthetic parameters in salt-treated beans. - Journal of Plant Nutrition and Soil Science 172: 637-643.

[11] Chaudhary, W. B., Ali, M. A., Bajwa, K. S., Iqbal, A., Khan, M. A., Shahid, A. A., Aslam, M. (2017): Correlation analysis of maize genotypes under saline stress and its impact on morphological characteristics. - Life Science Journal 14(7): 93-101.

[12] Chelli-Chaabouni, A., Ben Mosbah, A., Maalej, M., Gargouri, K., Gargouri-Bouzid, R., Drira, N. (2010): In vitro salinity tolerance of two pistachio rootstocks: Pistacia vera L. and $P$. atlantica Desf. - Environmental and Expermental Botany 69: 302-312.

[13] Cicek, N., Cakirlar, H. (2002): The effects of salinity on some physiological parameters in two maize cultivars. - Journal of Plant Physiology 28: 66-74.

[14] Claussen, W. (2005): Proline as a measure of stress in tomato plants. - Plant Science 168: 241-248.

[15] Cramer, G. R. (2002): Sodium-calcium interactions under salinity stress. - In: Lauchli, A. (ed.) Salinity: Environment - Plants - Molecules. Springer, Dordrecht, pp. 205-228.

[16] de Lacerda, C. F., Cambraia, J., Oliva, M. A., Ruiz, H. A., Prisco, J. T. (2003): Solute accumulation and distribution during shoot and leaf development in two sorghum genotypes under salt stress. - Environmental and Expermental Botany 49: 107-120.

[17] de Lacerda, C. F., Cambraia, J., Oliva, M. A., Ruiz, H. A. (2005): Changes in growth and in solute concentrations in sorghum leaves and roots during salt stress recovery. Environmental and Experimental Botany 54: 69-76.

[18] Demidchik, V., Straltsova, D., Medvedev, S. S., Pozhvanov, G. A., Sokolik, A., Yurin, V. (2014): Stress-induced electrolyte leakage: The role of $\mathrm{K}^{+}$permeable channels and involvement in programmed cell death and metabolic adjustment. - Journal of Experimental Botany 65: 1259-1270.

[19] Demiral, T., Türkan, İ. (2005): Comparative lipid peroxidation, antioxidant defense systems and proline content in roots of two rice cultivars differing in salt tolerance. Environmental and Experimental Botany 53: 247-257.

[20] Farooq, M., Hussain, M., Wakeel, A., Siddique, K. H. M. (2015): Salt stress in maize: effects, resistance mechanisms, and management. A review. - Agronomy for Sustainable Development 35: 461-481.

[21] Flowers, T. J., Flowers, S. A. (2005): Why does salinity pose such a difficult problem for plant breeders? - Agricultural water management 78: 15-24.

[22] Gao, Y., Lu, Y., Wu, M., Liang, E., Li, Y., Zhang, D., Yin, Z., Ren, X., Dai, Y., Deng, D., Chen, J. (2016): Ability to Remove $\mathrm{Na}^{+}$and Retain $\mathrm{K}^{+}$Correlates with Salt Tolerance in Two Maize Inbred Lines Seedlings. - Frontiers in Plant Science 7: 1716.

[23] Ghars, M. A., Parre, E., Debez, A., Bordenave, M., Richard, L., Leport, L., Bouchereau, A., Savoure, A., Abdelly, C. (2008): Comparative salt tolerance analysis between 
Arabidopsis thaliana and Thellungiella halophile, with special emphasis on $\mathrm{KC} / \mathrm{NaC}$ selectivity and proline accumulation. - Journal of Plant Physiology 165: 588-599.

[24] Guo, X., Zhou, G., Zhu, G., Jiao, X. (2019): Effects of calcium on emergence and seedling growth of castor bean under salinity stress. - Current Science 116: 12.

[25] Gupta, B., Huang, B. (2014): Mechanism of Salinity Tolerance in Plants: Physiological, Biochemical, and Molecular Characterization. - International Journal of Genomics, Article ID: 701596.

[26] Hendawy, S. F., Khalid, K. A. (2005): Response of sage (Salvia officinalis L.) plants to zinc application under different salinity levels. - Journal of Applied Sciences Research 1: 147-155.

[27] Hoque, M. A., Okuma, E., Banu, M. N. A., Nakamura, Y., Shimoishi, Y., Murata, Y. (2007): Exogenous proline mitigates the detrimental effects of salt stress more than exogenous betaine by increasing antioxidant enzyme activities. - Journal of Plant Physiology 164: 553-561.

[28] James, R. A., Blake, C., Byrt, C. S., Munns, R. (2011): Major genes for $\mathrm{Na}^{+}$exclusion, $\mathrm{Nax} 1$ and $\mathrm{Nax} 2$ (wheat HKT1; 4 and HKT1; 5), decrease $\mathrm{Na}^{+}$accumulation in bread wheat leaves under saline and waterlogged conditions. - Journal of Experimental Botany 62(8): 2939-2947.

[29] Jiang, Z., Song, G., Shan, X., Wei, Z., Liu, Y., Jiang, C., Jiang, Y., Jin, F., Li, Y. (2018): Association Analysis and Identification of ZmHKT1; 5 Variation with Salt-Stress Tolerance. - Frontiers in Plant Science 9: 1485.

[30] Kaya, C., Higgs, D. (2002): Calcium nitrate as a remedy for salt-stressed cucumber plants. - Journal of Plant Nutrition 25: 861-871.

[31] Kaya, C., Kirnak, H., Higgs, D., Saltali, K. (2002): Supplementary calcium enhances plant growth and fruit yield in strawberry cultivars grown at high $(\mathrm{NaCl})$ salinity. - Scientia Horticultrae 93: 65-74.

[32] Koca, H., Bor, M., Özdemir, F., Türkan, I. (2007): The effect of salt stress on lipid peroxidation, antioxidative enzymes and proline content of sesame cultivars. Environmental and Experimantal Botany 60: 344-351.

[33] Kwon, T. R., Siddiqui, Z. S., Harris, P. J. C. (2009): Effects of supplemental calcium on ion accumulation, transport and plant growth of salt sensitive Brassica rapa Landrace. Journal of Plant Nutrition 32: 644-667.

[34] Liu, C., Li, C., Liang, D., Wei, Z., Zhou, S., Wang, R., Ma, F. (2012): Differential expression of ion transporters and aquaporins in leaves may contribute to different salt tolerance in Malus species. - Plant Physiology and Biochemistry 58: 159-165.

[35] Liu, B., Luo, C., Li, X., Gray, L., Zhang, F., Liu, M. (2014): Research on the threshold of aluminum toxicity and the alleviation effects of exogenous calcium, phosphorus, and nitrogen on the growth of Chinese fir seedlings under aluminum stress. - Communications in Soil Science and Plan Analysis 45: 126-139.

[36] Loutfy, N., El-Tayeb, M. A., Hassanen, A. M., Moustafa, M. F. M., Sakuma, Y., Inouhe, M. (2012): Changes in the water status and osmotic solute contents in response to drought and salicylic acid treatments in four different cultivars of wheat (Triticum aestivum). Journal of Plant Research 125: 173-184.

[37] Maathuis, F. J. M., Sanders, D. (2001): Sodium uptake in Arabidopsis roots is regulated by cyclic nucleotides. - Plant Physiology 127: 1617-1625.

[38] Maeda, Y., Yoshiba, M., Tadano, T. (2005): Comparison of Ca Effect on the Salt Tolerance of Suspension Cells and Intact Plants of Tobacco (Nicotiana tabacum L., cv. Bright Yellow-2). - Soil Science \& Plant Nutrition 51: 485-490.

[39] Manivannan, P., Jaleel, C. A., Sankar, B., Somasundaram, R., Murali, P. V., Sridharan, R., Panneerselvam, R. (2007): Salt stress mitigation by calcium chloride in Vigna radiata (L.) Wilczek. - Acta biologica Cracoviensia Series botanica 49: 105-109. 
[40] Mansour, M. M. F., Salama, K. H. A., Ali, F. Z. M., Abou Hadid, A. F. (2005): Cell and plant responses to $\mathrm{NaCl}$ in Zea mays cultivars differing in salt tolerance. - General and Applied Plant Physiology 31: 29-41.

[41] Martínez-Alcántara, B., Martínez-Cuenca, M. R., Quiñones, A., Iglesias, D. J., PrimoMillo, E., Forner-Giner, M. A. (2015): Comparative expression of candidate genes involved in sodium transport and compartmentation in citrus. - Environmental and Experimenrtal Botany 111: 52-62.

[42] Martínez-Ballesta, M. C., Cabanero, F., Olmos, E., Periago, P. M., Maurel, C., Carvajal, M. (2008): Two different effects of calcium on aquaporins in salinity-stressed pepper plants. - Planta 228: 15-25.

[43] Misra, N., Gupta, A. K. (2005): Effect of salt stress on proline metabolism in two high yielding genotypes of green gram. - Plant Science 169: 331-339.

[44] Mulholland, B. J., Fussell, M., Edmondson, R. N., Basham, J., Mckee, J. M., Parsons, N. (2002): The effect of split-root salinity stress on tomato leaf expansion, fruit yield and quality. - The Journal of Horticultural Science and Biotechnology 77: 509-519.

[45] Munns, R., James, R. A. (2003): Screening methods for salinity tolerance: a case study with tetraploid wheat. - Plant and Soil 253: 201-218.

[46] Naher, N. (2014): Effect of salinity on soil and morpho-physiological attributes of tomato (Lycopersicon esculentum Mill.) at asasuni and kalapara coastal regions of Bangladesh. Ph.D. Thesis, Department of Environmental Science, Jahangirnagar University, Savar, Dhaka, Bangladesh.

[47] Nayyar, H., Chander, K., Kumar, S., Bains, T. (2005): Glycine betaine mitigates cold stress damage in Chickpea. - Agronomy for Sustainable Development 25: 381-388.

[48] Nedjimi, B., Daoud, Y. (2009): Ameliorative effect of $\mathrm{CaCl}_{2}$ on growth, membrane permeability and nutrient uptake in Atriplex halimus subsp. Schweinfurthii grown at high $(\mathrm{NaCl})$ salinity. - Desalination 249: 163-166.

[49] Netondo, G. W., Onyango, J. C., Beck, E. (2004): Sorghum and salinity: II. Gas exchange and chlorophyll fluorescence of sorghum under salt stress. - Crop Science 44: 806-811.

[50] Parvin, K., Ahamed, K. U., Islam, M. M., Haque, M. N. (2015): Response of Tomato Plant under Salt Stress: Role of Exogenous Calcium. - Journal of Plant Sciences 10(6): 222-233.

[51] Qadir, A., Khan, S. A., Ahmad, R., Masood, S., Irshad, M., Kaleem, F., Kumar, S., Shahzad, M. (2016): Exogenous $\mathrm{Ca}_{2} \mathrm{SiO}_{4}$ enrichment reduces the leaf apoplastic $\mathrm{Na}^{+}$and increases the growth of okra (Abelmoschus esculentus L.) under salt stress. - Scientia Horticulturae 214: 1-8.

[52] Rahneshan, Z., Nasibi, F., Moghadam, A. A. (2018): Effects of salinity stress on some growth, physiological, biochemical parameters and nutrients in two pistachio (Pistacia vera L.) rootstocks. - Journal of Plant Interactions 13(1): 73-82.

[53] Richter, J. A., Erban, A., Kopka, J., Zörb, C. (2015): Metabolic contribution to salt stress in two maize hybrids with contrasting resistance. - Plant Science 233: 107-115.

[54] Shabala, S., Newman, I. (2000): Salinity effects on the activity of plasma membrane $\mathrm{H}^{+}$ and $\mathrm{Ca}^{2+}$ transporters in bean leaf mesophyll: masking role of the cell wall. - Annals of Botany 85: 681-686.

[55] Shabala, S., Shabala, L., Volkenburgh, E. V. (2003): Effect of calcium on root development and root ion fluxes in salinized barley seedlings. - Functional Plant Biology 30: 507-514.

[56] Shabala, S., Shabala, L., Volkenburgh, E. V., Newman, I. (2005): Effect of divalent cations on ion fluxes and leaf photochemistry in salinized barley leaves. - Journal of Experimental Botany 56: 1369-1378.

[57] Shabala, S., Demidchik, V., Shabala, L., Cuin, T. A., Smith, S. J., Miller, A. J., Davies, J. M., Newman, I. A. (2006): Extracellular $\mathrm{Ca}^{2+}$ ameliorates $\mathrm{NaCl}$-induced $\mathrm{K}^{+}$loss from Arabidopsis root and leaf cells by controlling plasma membrane $\mathrm{K}^{+}$-permeable channels. Plant Physiology 141: 1653-1665. 
[58] Shoresh, M., Spivak, M., Bernstein, N. (2011): Involvement of calcium-mediated effects on ROS metabolism in the regulation of growth improvement under salinity. - Free Radical Biology and Medicine 51: 1221-1234.

[59] Sima, N. A. K. K., Askari, H., Mirzaei, H. H., Pessarakli, M. (2009): Genotype-Dependent Differential Responses of Three Forage Species to Calcium Supplement in Saline Conditions. - Journal of Plant Nutrition 32: 579-597.

[60] Soliman, W. S., El-Shaieny, A. H. (2014): Effect of saline water on germination and early growth stage of five Apiaceae species. - African Journal of Agricultural Research 9(7): 713-719.

[61] Sun, J., Gao, J., Wang, Z., Hu, S., Zhang, F., Bao, H., Fan, Y. (2018): Maize Canopy Photosynthetic Efficiency, Plant Growth, and Yield Responses to Tillage Depth. Agronomy 9: 3.

[62] Tahjib-Ul-Arif, M., Roy, P. R., Sohag, A. A. M., Afrin, S., Rady, M. M., Hossain, M. A. (2018): Exogenous Calcium Supplementation Improves Salinity Tolerance in BRRI Dhan28; a Salt-Susceptible High-Yielding Oryza Sativa Cultivar. - Journal of Crop Science and Biotechnology 21(4): 383-394.

[63] Taylor, N. L., Day, D. A., Millar, A. H. (2004): Targets of stress induced oxidative damage in plant mitochondria and their impact on cell carbon/nitrogen metabolism. - Journal of Experimental Botany 55: 1-10.

[64] Tuna, L., Kaya, C., Ashraf, M., Altunlu, H., Yokas, I., Yagmur, B. (2007): The effects of calcium sulphate on growth, membrane stability and nutrient uptake of tomato plants grown under salt stress. - Environmental and Experimental Botany 59: 173-178.

[65] Tuna, A. L., Kaya, C., Dikilitas, M., Higgs, D. (2008): The combined effects of gibberellic acid and salinity on some antioxidant enzyme activities, plant growth parameters and nutritional status in maize plants. - Environmental and Experimental Botany 62: 1-9.

[66] Veeranagamallaiah, G., Chandraobulreddy, P., Jyothsnakumari, G., Sudhakar, C. (2007): Glutamine synthetase expression and pyrroline-5-carboxylate reductase activity influence proline accumulation in two cultivars of foxtail millet (Setaria italica L.) with differential salt sensitivity. - Environmental and Experimental Botany 60: 239-244.

[67] Xu, D., Wang, W., Gao, T., Fang, X., Gao, X., Li, J., Bu, H., Mu, J. (2017): Calcium alleviates decreases in photosynthesis under salt stress by enhancing antioxidant metabolism and adjusting solute accumulation in Calligonum mongolicum. - Conservation Physiology, doi:10.193/CONPHYS/COX060.

[68] Yildirim, E., Taylor, A., Spittler, T. (2006): Ameliorative effects of biological treatments on growth of squash plants under salt stress. - Scientia Horticulturae 111: 1-6.

[69] Yildirim, E., Karlidag, H., Turan, M. (2009): Mitigation of salt stress in strawberry by foliar K, Ca and Mg nutrient supply. - Plant, Soil and Environment 55(5): 213-221.

[70] Yurtseven, E., Kesmez, G. D., Unlukara, A. (2003): The effect of potassium on salinity tolerance, fruit quality and water consumption for tomato (Lycopersicon esculentum) under saline conditions. - Sustainable Strategies for irrigation in salt prone Mediterranean Region. A: system approach proceeding of an International Workshop, Cairo, Egypt: 192203.

[71] Zafar-ul-Hye, M., Farooq, H. M., Zahir, Z. A., Hussain, M., Hussain, A. (2014): Application of ACC-deaminase Containing Rhizobacteria with Fertilizer Improves Maize Production under Drought and Salinity Stress. - International Journal of Agriculture and Biology 16: 591-596.

[72] Zhu, J. K. (2002): Salt and drought stress signal transduction in plants. - Annual Review of Plant Biology 53: 247-273. 